\title{
The industrial equilibrium exchange rate in Brazil: an estimation
}

NELSON MARCONI*

This paper presents a methodology for calculating the industrial equilibrium exchange rate, which is defined as the one enabling exporters of state-of-the-art manufactured goods to be competitive abroad. The first section highlights the causes and problems of overvalued exchange rates, particularly the Dutch disease issue, which is neutralized when the exchange rate strikes the industrial equilibrium level. This level is defined by the ratio between the unit labor cost in the country under consideration and in competing countries. Finally, the evolution of this exchange rate in the Brazilian economy is estimated.

Keywords: exchange rate; Dutch disease; deindustrialization; economic development.

JEL Classification: F43; O11; O14; O24.

\section{INTRODUCTION}

New developmentalism defines the exchange rate as a key variable in the development process according to its impact on investment decisions and economic growth. Because they define the ratio between the prices of tradables and nontradables, the exchange rate level and fluctuations influence the competitiveness of a country in foreign markets, the profitability of various sectors, the composition of aggregate demand, of investments and of the productive structure and, consequently, growth rates. Currency appreciation for prolonged periods can jeopardize

\footnotetext{
* From the São Paulo School of Economics of the Getulio Vargas Foundation and the Catholic University of São Paulo. The author thanks Luiz Carlos Bresser-Pereira, José Luíz Oreiro and Paulo Gala for their comments and Bruna Pezzin, Heitor Mota Fior, Marco Brancher, Pietro Consonni and Roberto Aragão for their assistance in the calculations made here. All errors and omissions are certainly the author's alone.
} 
the trade balance and alter its composition, increasing the relative share of primary goods in exports and of manufactured goods in imports (mainly intermediate goods), possibly leading to regressive specialization in the productive structure and deindustrialization. Bresser-Pereira $(2009,2011)$ emphasizes this phenomenon and his arguments are supported by Razmi et al. (2009), Rodrik (2008), Gala (2007) and Palma (2005), among other authors.

The exchange rate tends to be overvalued in countries suffering from the Dutch disease and/or with excessive capital inflows. While the influence of the latter on the exchange rate is cyclic, since it is associated with the difference between domestic and foreign interest plus the expected exchange rate - and to the attractiveness of investments in an economy - , the Dutch disease has a structural bearing on the exchange rate, as it is associated with a country's natural resource endowment characteristic. It is therefore necessary to neutralize its effects, since in this case the pressure brought about by over-appreciation cannot be relieved by market mechanisms. And for the Dutch disease process to be neutralized, the gap between what Bresser-Pereira (2008b) refers to as current equilibrium and industrial equilibrium exchange rates must be reduced.

Therefore, the aim of this paper is to estimate the industrial equilibrium exchange rate of the Brazilian economy using a methodology proposed by the author. For this purpose, the characteristics of the Dutch disease will be discussed to provide an understanding of the concept behind the industrial equilibrium exchange rate and of its effects on economic growth; subsequently, a methodology for calculating this exchange rate and estimating its evolution in the recent past will be presented.

\section{CHARACTERISTICS OF THE DUTCH DISEASE PROCESS}

According to Bresser-Pereira (2008), the Dutch disease is a market failure that makes it possible for a country to achieve a current account balance despite the exchange rate to be holding overvalued. Countries affected by this problem have abundant natural resources produced at a very low cost and, because of the scarcity of these products in the global market, their producers earn a Ricardian rent and they enjoy much higher revenues from exports (in foreign currency) leading to an overvalued exchange rate. Such appreciation reduces the revenues in Brazilian currency of exporters at large, but given the low production cost (a structural factor) of commodities, which is often associated with a higher international price caused by a higher demand (a cyclical factor), the exporters of these goods manage to preserve their profitability and presence in foreign markets.

However, for exporters of other goods whose production process is not favored by the same abundance of natural resources that ensure a high productivity or cost edge over their foreign competitors, profitability is jeopardized (and thus investments) when the exchange rate is appreciated. In developing countries, this is what happens to manufactured goods. The exchange rate level that would enable 
efficient producers of manufactured goods to export them and preserve their profitability, referred to here as the industrial equilibrium exchange rate, is higher than the exchange rate that would ensure a current account balance but actually alters the composition of exports and of the country's productive structure toward greater specialization in primary goods.

In this scenario, there would be two equilibrium exchange rates in an economy suffering from a Dutch disease process: one that Bresser-Pereira (2008) refers to as the current account equilibrium exchange rate, which ensures a current account balance intertemporally but leads to a regressive change in the productive structure of the economy; in such a situation, the commodity trade balance more than offsets the deficit in the trade balance for manufactured goods, but it contributes to the abovementioned change in the productive structure; the other one is the industrial equilibrium exchange rate, which enables producers of state-of-the-art manufactured goods with the capacity to compete in foreign markets to do so with a fair profit margin.

The magnitude of the Dutch disease process is defined by the difference between these two exchange rates, and the actual exchange rate must be brought to the industrial equilibrium level to avoid this undesirable change in the productive structure.

The effects of the Dutch disease are not restricted to changes in the composition of exports brought about by an overvalued exchange rate. An appreciated domestic currency also stimulates imports of intermediate and final goods, the impact of which on production and on the composition of the productive structure can be harmful. ${ }^{1}$ Problems are created for the manufacturing sector associated not only with profitability, but also with foreign competition derived from currency appreciation.

In response to currency appreciation, the purchasing power of wages and aggregate demand rise in the short term, as argued by Corden and Neary (1982). The higher demand for non-tradables brought about by the rise in disposable income is met by domestic production (given the features of these goods and services), which can result in changes in relative prices favoring them. As for commodities, the higher demand is also met by domestic production, given the abundant supply and productivity edge between domestic and foreign producers. However, in the case of manufactured goods, a relatively large share of this increased demand is met by imports, i.e., the currency appreciation will have a bearing on the composition of supply, reducing the share of domestic products in it. Increased competition brought about by the currency appreciation will also inhibit the transfer of rising unit labor costs to the prices of domestically produced manufactured goods, which rise less than the prices charged in other sectors of the economy.

Therefore, if producers of manufactured goods expect to see long-term cur-

\footnotetext{
${ }^{1}$ Marconi and Rocha (2012) show that the negative effect that increased imports of intermediate inputs have on the production chain and on the manufacturing share on value added prevailed in the Brazilian economy in recent years over the positive effects that cheaper imported inputs can bring about through greater vertical integration of exported manufactured goods.
} 
rency appreciation (and thus lower profit margins), investments will be discouraged, thus inhibiting productivity improvements that could offset the wage increase derived from a higher aggregate demand. As a result, the decrease in profits for such producers is further reinforced.

To offset this increase in average wage costs and, in the case of exporters, the additional decrease in their revenues (converted to the domestic currency) due to the exchange rate appreciation, producers of manufactured goods increase the share of imported inputs in their production process to take advantage of their cheaper price in domestic currency and thus reduce their average production cost. This affects the domestic production of intermediate goods, inter-industrial demand, the production chain, and production diversification. Thus, the rise in demand brought about by the increased purchasing power of workers resulting from an overvalued exchange rate would be increasingly met by imports, undermining not only the final goods industry, but also that of intermediate goods and thus the production chain. As a result of this process, growth in manufacturing is lower than in other sectors and its share in value added decreases.

Such an economy will grow at a slower pace, as the effects of manufacturing on economic growth (widely discussed by Kaldor (1966), Chenery et al. (1986), Bernat (1996), Marinho et al. (2002), Palma (2005) and Veeramani (2009), among others) will be thwarted. In addition, a country in such a situation may face balance-of-payment constraints in the medium term. As stated above, exchange appreciation alters the foreign trade and production framework, leading the economy to regressive specialization in primary goods and higher imports of manufactured goods. The change in the production structure, in turn, changes the income elasticity of imports, which increases as result of a relative drop in the production of manufactured goods, as well as the income elasticity of exports, which decreases because demand for them is less elastic in relation to income than demand for manufactured goods (Bresser, Oreiro and Marconi, 2012).

Thus, the Dutch disease process leads to a reprimarization of exports and increased imports of manufactured goods in economies enjoying significant comparative advantages in the production of primary goods, to a higher demand for non-tradables - due to the rise in domestic income - and to a lower share of manufacturing in value added and in the growth rate of the economy.

To prevent this dynamic, the Dutch disease must be neutralized by taxing exports of commodities by countries affected by it so as reduce sales abroad and reverse the exchange appreciation process by reducing the inflow of foreign exchange. Establishing a sovereign fund is another solution. Consequently, the exchange rate will raise to the industrial equilibrium level and the process described above will be avoided.

It is therefore necessary to know the level of the industrial equilibrium exchange rate to ensure the feasibility of strategies and policies designed to suppress overvaluation of the exchange rate, i.e., the difference between that rate and the one prevailing in the economy. In the next section, a methodological proposal for calculating this rate will be presented. 


\section{METHODOLOGY FOR CALCULATING THE INDUSTRIAL EQUILIBRIUM EXCHANGE RATE}

The industrial equilibrium exchange rate is one that enables efficient entrepreneurs, i.e. those who produce goods in the state-of-the-art technology, to remain competitive abroad. The necessary condition for this to occur is the equalization between their profit margins and those enjoyed by their competitors. In the process of producing manufactured goods, which is basically a transformation process, the main production cost (considering all production stages) is that of labor, contrasting with the production of primary goods, which are more natural-resource intensive and less labor-intensive. Therefore, a possible pricing rule that producers of manufactured goods might seek to adopt is the following one: ${ }^{2}$

$P_{T R A D}=M+A V C$

Assuming that $m=\frac{M}{P_{T R A D}}$,

$$
P_{T R A D}=\frac{1}{1-m} * A V C
$$

$$
\begin{aligned}
& A V C=\frac{W}{\lambda}, \text { or unit labor cost }(\mathrm{ULC})^{2}, \\
& P_{T R A D}=\text { price of tradable manufactured goods }
\end{aligned}
$$

$m=$ mark-up on the average unit cost, calculated as a percentage of the price.

$A V G=$ average unit cost

$W=$ wage rate

$\lambda=$ labor productivity

Thus, the prices of manufactured goods would be defined by setting a mark-up over average costs, which would be primarily composed of the unit labor cost.

A key condition for producers to continue to compete in foreign markets is that $m a=m b$, where

$a=$ all other competitors in the international market

$b=$ producer (exporter) in the country in question.

If the price of a manufactured good in the international market is uniform -

\footnotetext{
${ }^{2}$ Another possibility, which strictly speaking is more realistic, would be to define that $A V C=$ $a^{*} \frac{W}{\lambda}+(1-\alpha) *\left(P_{M} * E\right)$, where $P_{M}=$ price of imported inputs (in foreign currency) used in the production process, $E=$ nominal exchange rate, $\alpha=$ share of domestic inputs in the production process of the tradable good, and $(1-\alpha)=$ share of imported inputs in the same process. When the nominal exchange rate appreciates, $\alpha$ is likely to drop, reducing production costs and requiring a lower industrial equilibrium exchange rate to ensure a profit margin for exporters of manufactured goods, but it would contribute to reduce the share of manufacturing in value added (Marconi and Rocha, 2012). Since this is an undesirable effect, a simpler pricing process will be considered that measures only the exporting company's competitiveness based on unit labor costs, without it having to increase the share of imported inputs in the production process to try and ensure desired profit margins.
} 
which is a reasonable assumption, given the fierce competition prevailing in it and the average cost for exporters is rising more than that of its competitors, producers will have to sacrifice their profit margin (markup) to remain competitive, that is, not to lose their market share.

Thus, $P_{T R A D_{a}}=P_{T_{R A D}}$,

The condition for $m_{a}=m_{b}$ is $A V C_{a}=A V C_{b}$,

$$
\begin{aligned}
& A V C_{a}=U L C_{a} \\
& A V C_{b}=\frac{U L C_{b}}{E},
\end{aligned}
$$

$E=$ Nominal effective exchange rate between the currency of the country in which exporting company $b$ produces and the currencies of the countries in which their competitors in the international market $(a)$ produce.

Thus, for $m_{a}=m_{b}$,

$$
U L C_{a}=\frac{U L C_{b}}{E} \text {, and } E=\frac{U L C_{b}}{U L C_{a}}
$$

For the competitiveness of producer $b$ to be preserved, the nominal effective exchange rate should correspond to the ratio between her unit labor cost and the unit labor cost of her competitors. In aggregate terms, this exchange rate should correspond to the ratio between the unit labor cost for producing manufactured goods in country $\mathrm{b}$ and the weighted average of the unit labor cost for producing the same goods in countries in which her competitors produce them.

Multiplying both terms by $\frac{\frac{1}{P_{b}}}{\frac{1}{P_{a}}}$, where:

$P_{a}=$ weighted average price level in the countries in which competitors of $b$ produce the goods,

$P^{b}=$ price level in the country in which producer $b$ produces the goods,

$$
\begin{aligned}
& E * \frac{1 / P_{b}}{1 / P_{a}}=\frac{U L C_{b}}{U L C_{a}} * \frac{1 / P_{b}}{1 / P_{a}}= \\
& \frac{E \cdot P_{a}}{P_{b}}=\frac{\frac{U L C_{p}}{P_{b}}}{\frac{U L C_{a}}{P_{a}}}
\end{aligned}
$$

If the average cost per unit is basically composed of the unit labor cost, the real exchange rate of a country will be at a satisfactory level - to preserve the competitiveness of its producers of manufactured goods in foreign markets - when it is equal to the ratio between the unit labor costs, in real terms, of $b$ and $a$. If it 
is lower, it will be over-appreciated for producers of manufactured goods in the country under analysis and vice versa.

The industrial equilibrium concept is therefore a microeconomic concept that is used to define a fundamental macroeconomic price in any economy - the exchange rate. The best way to calculate it is by defining a sample of companies using global state-of-the-art technology and calculating, for each of them, the exchange rate that would enable them to export with satisfactory profit margins. From the aggregate standpoint, the value of the unit labor cost in manufacturing in a country and for competitors could be also calculated. However, establishing such a sample or making any of these two calculations is not possible. Therefore, the ratio between the unit labor cost in $a$ and $b$, as shown in equations (3) or (4), is calculated as a relative or index number that can be used for estimating the evolution of the real industrial equilibrium exchange rate, but not its level.

In order to estimate its level over time, a basis for calculation must be established. It should correspond to a level of the real effective exchange rate for manufactured goods that is recognized as close to industrial equilibrium. Once the value of this effective rate and the period over which such threshold prevails are defined, the subsequent variation of the ratio between the unit labor cost (ULC) in $a$ and $b$ to the present day is applied to estimate the evolution of the industrial equilibrium exchange rate.

The real effective exchange rate for manufactured goods is also an index; to estimate its corresponding level, one should choose an average nominal exchange rate in a period close to the present and apply variations in the real effective exchange rate retroactively from there. In the next section, the industrial equilibrium exchange rate will be estimated using the calculation methodology described above.

\section{ESTIMATING THE INDUSTRIAL EQUILIBRIUM EXCHANGE RATE FOR BRAZIL}

The first step in this estimation is setting the value of the real effective exchange rate that will be equivalent to the base of the series, from which level the evolution of the ratio between the unit labor cost in Brazil and in its trading partners' countries will be applied. This value should correspond to an exchange rate level identified as that of industrial equilibrium. A decision was thus made to select the real exchange rate value rate in a period in which: a) the exchange rate was managed; b) the country neutralized the Dutch disease process; c) the share of manufacturing in value added was not declining, so as to confirm that the real exchange rate stood at a satisfactory level. ${ }^{3}$

\footnotetext{
${ }^{3}$ Another possibility would be to apply the average tariff charged on imports and exports during the period in which the country was neutralizing the Dutch disease (thus before the trade and capitalaccount liberalization drive in the early 1990s) to the current equilibrium exchange rate. However, neither of these two pieces of information - tariffs and exchange rate resulting in intertemporal equilibrium in the current account balance - are available a priori.
} 
For building an effective exchange rate for manufactured goods that is sufficiently retroactive, one must know the share of the different partners involved in the Brazilian trade flow in such products in a distant past and, unfortunately, this information is not available. For this reason, in order to build a series of the real exchange rate over a longer period, only the evolution of the bilateral exchange rate between Brazil and the US was considered, as calculated for the 1950-2012 period. The deflators are the wholesale price indices of the two countries and the base of the series is the value of the average nominal exchange rate in 2010. It was decided that this base would be set in a close period, so that the values of the series to be calculated would be comparable to those seen today, more specifically in 2010 , as this is the last year in the series for the unit labor cost (as per the availability of data). ${ }^{4}$

When the base of the real exchange rate is defined as the value of the nominal exchange rate in a given period, its value is equal to:

$$
z_{t}=\bar{E}_{i} * \frac{e_{t}}{\bar{e}_{i}}
$$

Where:

$z_{t}=$ value of the real exchange rate in period $t$, calculated from the new base;

$\bar{E}_{i}=$ average nominal exchange rate in period $i$, defined as the new base;

$e_{t}=$ index number of the real exchange rate in period $t$, in the original base;

$\bar{e}_{i}=$ average index number of the real exchange rate in period $i$, in the original base.

Graph 1 shows that this series (as calculated for monthly values and referred to as the bilateral real exchange rate) was relatively stable between 1968 and 1979, indicating that the policy makers managed the exchange rate to prevent it from over-appreciating; in addition, the following structural changes took place in the Brazilian economy over this period: a) the share of manufactured goods in exports increased significantly; in 1964, it amounted to $9.3 \%$; in 1968 , it rose to $14 \%$ and in 1979 to $44.1 \%$ (just to illustrate the point, there was a peak in 1993 , at $61.3 \%$, and this percentage dropped to $36.8 \%$ in 2011 ); b) the share of manufacturing in value added increased to its highest level during this period — average of $21.1 \%$ at constant 1995 prices (by way of comparison, in 2011 this share dropped to $14.6 \%)$. Data calculated by the author based on data from the National Accounts, Funcex and Doellinger et al. (1973). It should also be noted that, in the 1968-1970 period, the Dutch disease process was neutralized by applying customs tariffs.

\footnotetext{
${ }^{4}$ The values of the series were also calculated on the base corresponding to the average nominal rate in 2009 and 2011 and the results were very similar. It is important to note that this base is just used to calculate the level of the exchange rate over time, according to the real evolution of its index. It is distinct from the base that corresponds to the approximate value of the industrial equilibrium exchange rate, from which level the evolution of the ratio between the unit labor cost in Brazil and in its trading partners' countries will be applied. This other base will be estimated in the following step of this calculus.
} 
Graph 1: Bilateral real exchange rate - Brazil / USA and Real effective exchange rate for exports of manufactured goods Average monthly values Deflators: PPI BR and PPI USA

(Bilateral RER) and PPI (at manufacturing) for Brazil and PPI for other countries (Effective RER) Base = average nominal R / US\$ exchange rate in 2010

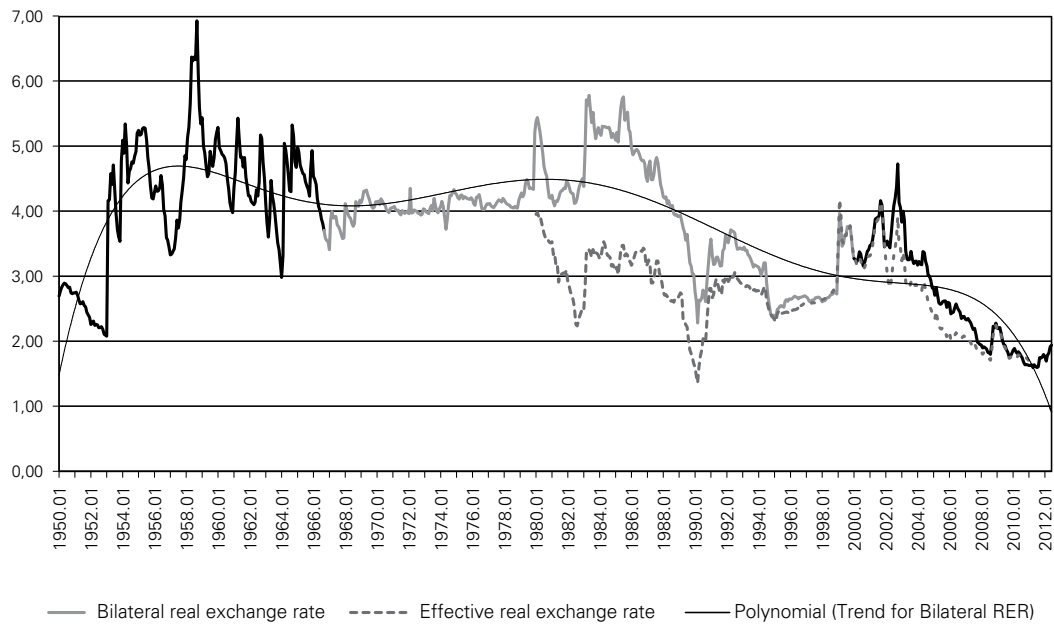

Source: Ipeadata; prepared by the author.

Thus, based on these data, it can be estimated that, between 1968 and 1979, the real exchange rate stood at a favorable level for boosting exports and the share of manufacturing in value added, meaning that it was at a level that can be referred to as that of industrial equilibrium. In the series calculated according to the criterion defined in Equation 5, this level would be R 4.09 (average for the 1968-1979 period), which in turn is very similar to the average level registered in 1988 ( $\mathrm{R} \$ 4.07)$, the year from which data series for the evolution of the unit labor cost for most of Brazil's trade partners are available. ${ }^{5}$ This way, the real average exchange rate in 1988 is defined as a value corresponding to the industrial equilibrium level, from which variations in the ratio between the unit labor cost in Brazil and in its trading partners' countries will be applied.

However, one should remember that the real exchange rate calculated according to the above-mentioned criterion is bilateral, meaning that it does not take into account other trade partners of Brazil and neither specifies those that are more relevant for the trade in manufactured goods. A real exchange rate possessing these features was calculated by Ipeadata based on post- 1980 data ${ }^{6}$ A possible strategy to address this problem would thus be one of calculating the value of the real ex-

\footnotetext{
${ }^{5}$ Recalling once again that this value was calculated for a series whose base is the average nominal exchange rate in 2010.

${ }^{6}$ The real exchange rate mentioned is the one calculated by IPEA for manufactured products, with wholesale price indices as deflators, which are better indicators of the evolution of costs for producers than retail indices. This rate is actually a weighted average index of bilateral exchange rates between Brazil and its main trading partners in manufactured goods. The weight is calculated according to the
} 
change rate for the Ipeadata series according to the criterion defined in Equation 5 , adopting the same base period (average nominal value in 2010) and establishing, once again, the average calculated in 1988 as that of industrial equilibrium, namely, $\mathrm{R} \$ 2.67$. This series is also included in chart 1 as the real effective exchange rate.

To validate this strategy, the series of the bilateral exchange rate calculated by the author and that of the effective exchange rate estimated by Ipeadata and also recalculated should have a high correlation. The correlation between the monthly values for the two series is indeed significant: $77.7 \%$ over the whole period during which the series coexist (1980-2011), 77.5\% between 1980 and 1989, thus defined because it is the one in which the values in the series have the largest gap, as shown in Graph 1, and $91.3 \%$ in the $1990-2011$ period. $^{7}$

Once the base year for calculating the industrial equilibrium exchange rate is set at 1988 and its magnitude is defined as the corresponding value of the average real effective exchange rate in that period at 2010 prices, one must apply variations in the index that measures the ratio between the unit labor cost (in real terms) in Brazil and in its partners' countries (idem) after 1988 to estimate the value of the industrial equilibrium exchange rate over time.

As defined above,

$$
U L C=\frac{W}{\lambda}=\frac{W_{m}}{N} / \frac{Y}{N}=\frac{W m}{Y}
$$

Where:

$$
\begin{aligned}
& U L C=\text { unit labor cost } \\
& W=\text { wage rate } \\
& \lambda=\text { productivity } \\
& W_{m}=\text { total earnings } \\
& N=\text { number of employees } \\
& Y=\text { value added }
\end{aligned}
$$

The unit labor cost is therefore calculated by dividing the index for the evolution of total earnings in manufacturing and the value added index in the same sector. OECD and the Bureau of Labor Statistics, which are the sources of information on most of our trading partners, measure an index for the average annual

\footnotetext{
share of the 16 main trading partners of Brazil in our total exports of manufactured exports in 2001. See www.ipeadata.gov.br.

${ }^{7}$ Another implicit assumption in this strategy is that the series of the real effective exchange rate also has a high correlation with the series of the real bilateral exchange rate throughout the 1970s. This assumption is necessary because the series of the effective exchange rate for the 1970s is not known; thus, future improvements in the estimate made in this article will include that of calculating the real effective exchange rate for manufactured products for a longer period.
} 
evolution of the unit labor cost for several countries based on this criterion (in nominal terms - total earnings in nominal terms/value added in real terms), which the author then converted into an index for real evolution using the respective consumer price indices (annual average) as deflators. For Brazil, given the evolution of inflation over the period under consideration, a monthly series was calculated by the division between the real payroll index and the real production index (both of which are calculated and disseminated by IBGE based on its industrial surveys) and then the annual average of the values of this series was calculated. It should be noticed that the result of calculating the unit labor cost is an index, which therefore only indicates its evolution. ${ }^{8}$

Subsequently, an average of the indices representing the evolution of the unit labor cost, in real terms, for Brazil's main trading partners for manufactured goods was estimated. The weight was the share of each of these trading partners in these products' trade flow with Brazil. Both exports and imports were considered, as the goal is that of knowing the exchange rate that makes exporters competitive and avoids distortions in the prices of imported goods, causing them to drop too much, thus leading to excessive consumption of imported products. The ratio between the unit labor cost evolution index in Brazil and its average evolution in its trading partners' countries is an indicator of the country's competitiveness that in reality represents the evolution of its industrial equilibrium exchange rate. ${ }^{9}$

Graph 2 shows the unit labor cost evolution index (in real terms) in Brazil and in its main trading partners' countries (on average) and the ratio between these indices. A drop in the ratio between these indexes constitutes a gain in competitiveness for Brazil. ${ }^{10}$ During the period under consideration, it can be seen that Brazil experienced competitive gains (considering the calculation criterion adopted in this paper, based on variations in the unit labor cost) in relation to its partners until 2000, when the ratio stabilized and subsequently, from 2003 onward, Brazil lost the competitive edge it had achieved earlier in the period and found itself in a worse situation than that observed in 1988. Because the unit labor cost rose, one can also see that productivity did not evolve in pace with real wages in manufacturing in the Brazilian economy after 2007 (with the exception of 2010). ${ }^{11}$

\footnotetext{
${ }^{8}$ For countries for which information is not available in the OECD database, an effort was made to use the same calculation methodology. Details about the criteria can be provided by the author.

${ }^{9}$ The countries considered in the estimate, sources of data and weights that were used are described in Annex.

${ }^{10}$ The series starts in 1988 due to the availability of data for most countries from that date and because this year was defined as the base for calculating the industrial equilibrium exchange rate.

11 The figure for 2011 was calculated for Brazil from existing data sets and for the other countries it was estimated that the real unit labor cost would remain constant. The only country for which data for 2011 are already available, the United States, seems to have a stable nominal unit labor cost $(-0.1 \%$, according to data from the Bureau of Labor Statistics), which implies in a reduction in real terms. Thus, by assuming a stable unit labor cost for Brazil's trading partners, an optimistic assumption is adopted for the evolution of the competitiveness of Brazilian exporters of manufactured goods in 2011.
} 
The link between the value of the real effective exchange rate in 1988 and variations in the index applied to measuring the competitiveness of our exporters of manufactured goods results in an estimate of the average annual values of the industrial equilibrium exchange rate at 2010 prices. Thus the series for the competitiveness indicator included in Chart 2 also corresponds to the evolution of the real industrial equilibrium exchange rate, the initial value of which being equivalent to the one previously calculated for 1988 (R\$2.67). The evolution of the competitiveness indicator allows one to estimate that the value of the real industrial equilibrium exchange rate stood at $\mathrm{R} \$ 2.65$ in 2010 , which is virtually the same value estimated for 1988, and at US\$ 2.75 in 2011.

Graph 2: Real unit labor cost in Brazil and trading partners (2005 $=100)$ and industrial equilibrium real exchange rate (evolution = competitive index) (Base $=1988$ value, at 2010 prices)

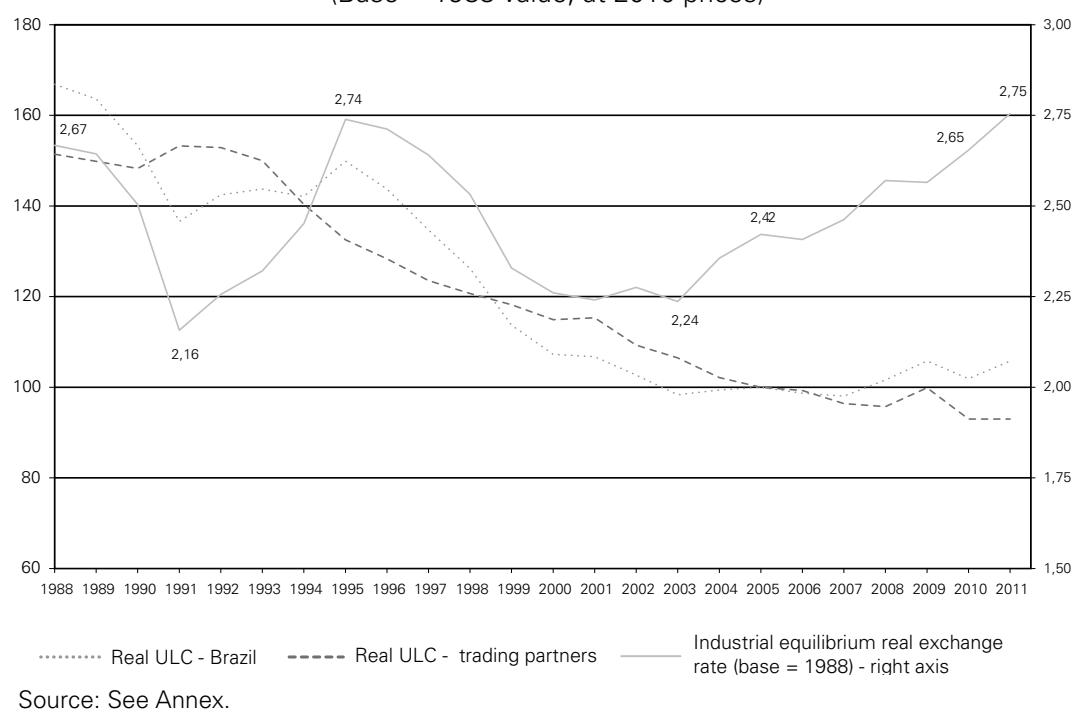

Given all the assumptions considered in the calculation carried out according to the methodology proposed here, it should be emphasized that the resulting rate should not be seen as an exact value. A better approach would be that of considering that the industrial equilibrium exchange rate would stand at an interval around this value. Thus, due to the model and the estimates made, it is assumed that if the observed exchange rate stool at a level close to $\mathrm{R} \$ 2.75$, efficient enterprises producing manufactured goods would be encouraged to look for ways to increase their sales abroad and would be exposed to a less unequal competition in relation to importers, given the change that would take place in relative prices. This scenario would contribute to recovery in our manufacturing sector. For this exchange rate level to be achieved, interest rates must continue to be reduced and the Dutch disease process neutralized, as both of them lead to the appreciation of our currency. 


\section{REFERENCES}

BERNAT, G. Does Manufacturing Matter? A Spatial Econometric View of Kaldor's Laws, Journal of Regional Science, 36 (3), 1996.

BRESSER-PEREIRA, L. C. A taxa de câmbio no centro da teoria do desenvolvimento. Disponível em: $<$ http://www.bresserpereira.org.br/papers/2011/11.24.Macro_cambio_teoria_desenvolv_n_destin. pdf>. Draft paper, 2011.

BRESSER-PEREIRA, L. C. Globalização e Competição. Rio de Janeiro: Elsevier-Campus, 2009.

BRESSER-PEREIRA, L. C. The dutch disease and its neutralization: a Ricardian approach. Revista de Economia Política, v. 28, n. 1, pp. 47-71, 2008.

BRESSER-PEREIRA, L. C.; OREIRO, J.L.; MARCONI, N. A theoretical framework for a Structuralist Development Macroeconomics. Draft paper, 2012.

CARLOS VON DOELLINGER et al. Transformação da Estrutura de Exportações Brasileiras: 1964/70. Relatório de Pesquisa No. 14 INPES/IPEA (Rio de Janeiro: INPES/IPEA, 1973)

CHENERY, H.; SHERMAN, R.; MOSHE, S. Industrialization and growth. Oxford University Press, published for the World Bank, 1986.

CORDEN, W. M.; NEARY, P. Booming sector and de-industrialisation in a small open economy. Economic Journal, v. 92, n. 368, 1982.

GALA, P. Política cambial e macroeconomia do desenvolvimento. Tese (Doutorado) - Fundação Getulio Vargas, São Paulo, 2007.

KALDOR, N. Causes of the slow rate of economic growth in the United Kingdom, 1966. In: TARGETTI, F.;THIRLWALL, A. P. (Ed.).The Essential Kaldor. Holmes \& Meier Publishers, New York, 1989.

MARCONI, N.; ROCHA, M. Insumos importados e evolução do setor manufatureiro no Brasil. Texto para discussão IPEA, to be published, 2012.

MARINHO, E. L. L.; NOGUEIRA, C. A. G.; ROSA, A. L. T. Evidências empíricas da lei de Kaldor-Verdoorn para a indústria de transformação do Brasil (1985-1997). Revista Brasileira de Economia, Rio de Janeiro, v. 56. n. 3, jul.-set. 2002.

PALMA, G. Four sources of 'de-industrialisation' and a new concept of the dutch disease. In: OCAMPO, J. A. (Org.). Beyond reforms: structural dynamics and macroeconomic vulnerability. Stanford University Press and World Bank, 2005.

RAZMI, A.; RAPETTI, M.; SKOTT, P. The real exchange rate as an instrument of development policy. Working Paper 2009-07. Department of Economics, University of Massachusetts Amherst, 2009.

RODRIK, D. The real exchange rate and economic growth: theory and evidence. Weatherhead Center for International Affairs, Harvard University, 2008 (Working Paper, 2008-0141).

VEERAMANI JR., C. Impact of Imported Intermediate and Capital Goods on Economic Growth: A Cross Country Analysis. Indira Gandhi Institute of Development Research, 2009.

\section{ANNEX}

\section{DEFINITION OF THE WEIGHT FOR CALCULATING THE AVERAGE UNIT LABOR COST FOR BRAZIL'S MAIN TRADE PARTNERS}

The first step in this calculation included identifying countries with a more significant share in Brazil's annual trade flow (exports and imports at current values). Adjustments were subsequently made in this list of countries according to the availability of information on the unit labor cost. These countries account for $69 \%-90 \%$ of Brazil's total trade flow each year.

Intervals in which a particular weighing prevails were then defined. The criterion for grouping periods was the observation of a relative stability in the coun- 
tries' share in the trade flow; when data suggested a more significant change in this share, another interval was established.

The weight is the average share of the countries in question in the trade flow in the years considered in each interval. A specific weight was calculated for 2009 and 2010 due to changes in the set of countries for which data were available for these periods.

The table below includes the selected countries and their share in the calculation of the average unit labor cost (of our trade partners) in each interval considered:

Share (\%) of partners in Brazilian trade flow

\begin{tabular}{|l|c|c|c|c|c|c|}
\hline Country & $1988-93$ & $1994-98$ & $1999-04$ & $2005-08$ & 2009 & 2010 \\
\hline Germany & $11,8 \%$ & $11,2 \%$ & $7,6 \%$ & $7,4 \%$ & $8,2 \%$ & $7,6 \%$ \\
\hline Argentina & $8,2 \%$ & $15,4 \%$ & $9,9 \%$ & $11,4 \%$ & $11,6 \%$ & $12,6 \%$ \\
\hline Belgium & $2,3 \%$ & $2,0 \%$ & $1,4 \%$ & $1,4 \%$ & $1,3 \%$ & $1,2 \%$ \\
\hline Canada & $2,7 \%$ & $2,1 \%$ & $1,4 \%$ & $1,6 \%$ & $1,1 \%$ & $1,3 \%$ \\
\hline Chile & - & - & $1,9 \%$ & $2,0 \%$ & $1,6 \%$ & $1,6 \%$ \\
\hline China & - & - & $3,1 \%$ & $8,6 \%$ & $11,9 \%$ & $13,2 \%$ \\
\hline South Korea & $1,0 \%$ & $2,4 \%$ & $2,0 \%$ & $2,6 \%$ & $3,2 \%$ & $4,0 \%$ \\
\hline Spain & $1,2 \%$ & $2,0 \%$ & $1,9 \%$ & $1,6 \%$ & $1,5 \%$ & $1,8 \%$ \\
\hline United States & $38,7 \%$ & $32,2 \%$ & $29,1 \%$ & $20,1 \%$ & $17,1 \%$ & $15,5 \%$ \\
\hline France & $3,8 \%$ & $3,4 \%$ & $3,4 \%$ & $3,0 \%$ & $3,1 \%$ & $1,5 \%$ \\
\hline Italy & $6,5 \%$ & $7,1 \%$ & $4,2 \%$ & $3,2 \%$ & $3,2 \%$ & $2,9 \%$ \\
\hline Japan & - & - & $4,4 \%$ & $3,5 \%$ & $3,9 \%$ & $3,1 \%$ \\
\hline Mexico & $1,9 \%$ & $2,1 \%$ & $3,5 \%$ & $3,6 \%$ & $3,2 \%$ & $3,7 \%$ \\
\hline The Netherlands & $2,7 \%$ & $2,7 \%$ & $1,7 \%$ & $1,6 \%$ & $1,9 \%$ & $3,3 \%$ \\
\hline Portugal & $3,8 \%$ & $1,8 \%$ & $0,5 \%$ & $0,3 \%$ & $0,3 \%$ & $1,9 \%$ \\
\hline United Kingdom & $2,2 \%$ & $2,3 \%$ & $2,8 \%$ & $2,0 \%$ & $1,9 \%$ & $0,3 \%$ \\
\hline Sweden & $1,2 \%$ & $1,7 \%$ & $1,3 \%$ & $1,0 \%$ & $0,8 \%$ & $1,9 \%$ \\
\hline Taiwan & $2,0 \%$ & $2,4 \%$ & $1,2 \%$ & $1,5 \%$ & $1,6 \%$ & $0,9 \%$ \\
\hline Venezuela & - & - & $1,1 \%$ & $1,9 \%$ & $1,4 \%$ & $0,9 \%$ \\
\hline Total (of countries included & $81,8 \%$ & $90,8 \%$ & $78,5 \%$ & $74,1 \%$ & $74,7 \%$ & $69,9 \%$ \\
\hline in the estimate only) & & & & & & \\
\hline
\end{tabular}

The gray cells indicate that there is no information about the trade flow (-) or about the unit labor cost (the share of the country is included on the table, but it is highlighted).

Data source:

Argentina: Indec, Undata and IPC-7 provincias

Brasil: IBGE

China: Undata, Laborsta, IMF and People's Bank of China

Germany, Belgium, Canada, South Korea, Spain, France, Italy, Japan, The Netherlands, Portugal, United Kingdom,

Sweden and Mexico - OECD

Chile: Extended Penn World Tables v. 4.0

United States: OECD and Bureau of Labor Statistics (BLS)

Taiwan: BLS

Venezuela: Extended Penn World Tables v. 4.0 